\title{
Effect of Three Different Polishing Techniques on Surface Roughness and Bacterial Adhesion of Two Composite
} Resin

\author{
Daneshkazemi AR', Davari AR', Shirkhoda M$^{2}$, \\ Zandi $\mathrm{H}^{3}$ and Behniafar $\mathrm{B}^{4 *}$ \\ ${ }^{1}$ Department of Operative Dentistry, Social Determinant \\ of Oral Health Research Center, Shahid Sadoughi \\ University of Medical Sciences, Iran \\ ${ }^{2}$ Tehran University of Medical Sciences, Iran \\ ${ }^{3}$ Department of Microbiology, Faculty of Medicine, \\ Shahid Sadoughi University of Medical Sciences, Iran \\ ${ }^{4}$ Department of Restorative Dentistry, Faculty of \\ Dentistry, Tehran University of Medical Sciences, Iran \\ *Corresponding author: Behniafar B, Department \\ of Restorative Dentistry, Faculty of Dentistry, Tehran \\ University of Medical Sciences, North Kargar, Tehran, \\ Iran
}

Received: January 28, 2018; Accepted: February 21, 2018; Published: March 16, 2018

\begin{abstract}
Background and Aim: Resin composites are widely used in restorations. The adhesion of bacterial plaque to restorations depends on the surface properties and the composition of materials. As the Streptococcus Mutans has a major role in primary and secondary caries, the purpose of this in-vitro study was to examine the effect of different surface treating techniques on surface roughness and the amount of bacterial plaque adhesion on two types of resin composites.
\end{abstract}

Materials and Methods: 120 samples $(3 \times 6 \mathrm{~mm})$ of each Filtek Z250xt (3MESPE) and Filtek P90 (3MESPE) were produced and randomly divided into 4 surface treatment techniques: 1) composite resin surface in contact with mylar strip with no finishing or polishing performed. 2) Soflex aluminium oxide disc (3MESPE) 3) silicon-carbide rubber points (Politip P and F: Ivoclar Vivadent) 4) felt wheel with diamond paste (Diamond Excel: FGM). Surface roughness was measured with a profilometer. Test specimens were subjected to S.Mutans (PTCC 1683) biofilm development. The S.Mutans biofilm was calculated and recorded by the mean log of CFU/ml. The data was statistically analyzed by One-way and Two-way ANOVA analysis of variance and the Bonferroni test $(\mathrm{P}<0.05)$.

Results: The mylar strips showed the lowest amount of surface roughness in the two type of resin composites. While in the P90 composite, using the mylar strips had the highest amount of bacterial adhesion. The composite type and the surface treatment methods had significantly influenced the surface roughness and the bacterial adhesion.

Conclusion: Using different polishing techniques after polymerization of P90 in contact with mylar strips significantly reduces the bacterial plaque adhesion.

Keywords: Composite, Surface roughness, Bacterial plaque, Surface treatment

\section{Introduction}

Resin composites are extensively used in anterior and posterior restorations [1]. The composite resins have been developed to minimize the critical drawbacks of the polymer-based materials such as polymerization contraction, fatigue, occlusal wear, organic matrix degradation, surface roughness, insufficient contour and fractures $[2,3]$. Surface treatments such as finishing and polishing have an important role in clinical performance of these resin-based materials [4]. The finishing procedure is required to refine the anatomy of the restoration, whereas the polishing procedure aims at reducing the surface roughness produced by finishing appliances [4]. Composite's surface roughness also depends on the chemical composition and mechanical properties of these restorative materials [5-7].

In resin composites composition, the organic matrix and the inorganic fillers have different hardness values and in consequence present contrasting wear properties due to occlusal loads. The organic component wears rapidly and exposes the inorganic fillers, which are dislodged by attrition. Therefore, higher surface roughness is achieved due to larger particle size of the inorganic fillers [8-12]. Furthermore, surface roughness value is an important factor in microbial plaque accumulation on composite surface in clinical situations [13-15]. In the point of fact, the type, size and amount of inorganic fillers have effect on mechanical properties and polishing of composite resins [16]. Therefore resin composites with wide distribution of nano-sized fillers, have been produced because of improved mechanical and esthetic properties [7,11]. Streptococcus Mutans is the most prevalent bacteria in secondary caries; therefore well-polished composite surfaces reveal a noticeably reduced amount of bacterial adherence and colonization [2].

Weinmann, et al. claimed that silorane based restorations have lower potential to absorb the dyes of the daily nutrition due to their silorane subcomponent, which has a hydrophobic property in the material. Therefore it can be supposed that silorane-based composites can have less potential for bacterial adhesion [17]. However there is
Austin J Dent - Volume 5 Issue 4 - 2018

ISSN : 2381-9189 | www.austinpublishinggroup.com

Behniafar et al. (C) All rights are reserved
Citation: Daneshkazemi AR, Davari AR, Shirkhoda M, Zandi H and Behniafar B. Effect of Three Different Polishing Techniques on Surface Roughness and Bacterial Adhesion of Two Composite Resin. Austin J Dent. 2018; 5(4): 1110 


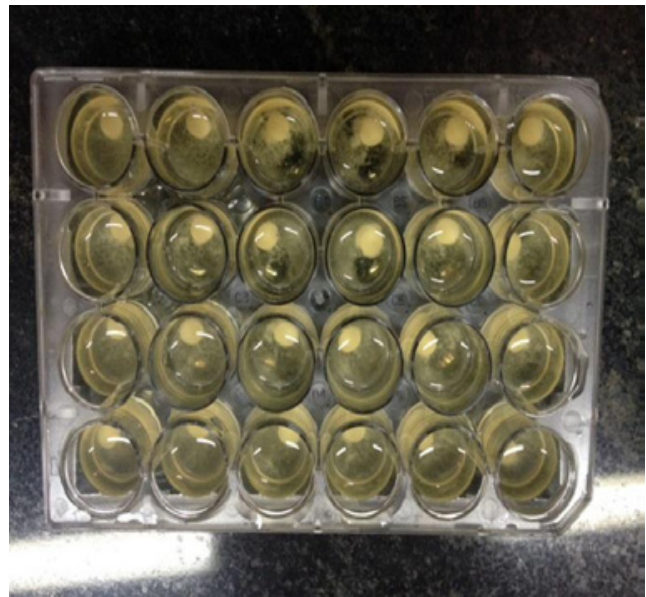

Figure 1: 24 well plated tissue culture.

no distinct information about their potential of bacterial adhesion, which can have a considerable influence on their clinical longevity. Aluminum-oxide disks can be used for finishing and polishing of composite resins, however because of their shape, they are not used in occlusal surfaces and are mostly applied in proximal surfaces [6,8,11,18-21]. Multi-fluted carbide burs, diamond burs, brushes , abrasive pastes and silicon carbide burs are commonly used in order to have well-polished occlusal posterior surfaces [21,23]. A perfect polished composite surface illustrates extreme esthetics and significant decrease in initial bacterial adherence and colonization. Furthermore, polishing of a composite restoration will decrease periodontal disease, marginal staining and secondary caries which originate from S. Mutans and S.Sobrinus [8,11,12,24-27]. Generally, the most reason for replacement of composite restorations is secondary caries which has effect on the durability of the restorations. The formation of biofilm and bacterial colonization on composite restorations may result in secondary caries [28-31]. Based on the facts described, the aim of this study was to evaluate the adherence of S.Mutans on the surface of Silorane-based (P90) and nanohybrid (Z250xt) composites which have been polished with aluminum-oxide discs, rubber points and polishing paste (and a control group with mylar strips). The correlation between bacterial adherence value and surface roughness of each prepared composite sample was estimated.

\section{Methods and Materials}

Composition information of two type of composites used in this study are presented in Table 1. 120 sample of each composite was prepared within a custom cylindrical-shaped steel mold $(6 \mathrm{~mm}$ in diameter and $3 \mathrm{~mm}$ in height). The mold was filled with $1.5 \mathrm{~mm}$ increments of composite resin and the final increment was carved with mylar matrix strip. The top surface was cured for 40 seconds with a light curing device (Demi: Kerr-USA with $800 \mathrm{mw} / \mathrm{cm}^{2}$ intensity). Samples were removed out from the mold and the excess composite was cut by surgical blade. Samples were immersed in black vials occupied with $37^{\circ} \mathrm{C}$ distilled water for 24 hours [32].

\section{Polishing techniques}

120 specimens of each composite were randomly divided into four subgroups of surface polishing techniques $(n=30)$ after removing the mylar strip.

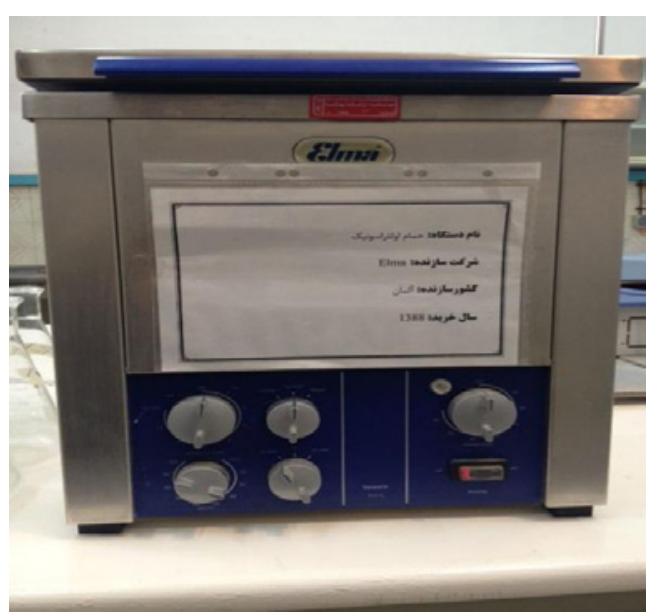

Figure 2: Ultrasonic bath.

A) No finishing or polishing technique is applied:

The surface of the specimens were remained intact after remaining the mylar strip (control group)

B) Aluminum-oxide discs (Soflex 3M ESPE) are applied:

In sequence of coarse $(100 \mu \mathrm{m})$, medium $(29 \mu \mathrm{m})$, fine $(14 \mu \mathrm{m})$, superfine $(5 \mu \mathrm{m})$ for 30 seconds in a single direction on the surface of specimens; and between the application of each disc, the surface was rinsed for 5 seconds and dried [32,33].

Each disc was changed after every 5 specimens.

C) Rubber points ( politip P and E: Ivoclar Vivadent, USA):

The specimens were smoothed for 60 seconds with white stone at first, washed and air dried for 5 seconds and then polished with a sequence of grey and green stones for 60 seconds each in a single direction [33].

D) Polishing paste (Diamond Excel; FGM; USA):

The surfaces of the specimens were polished with polishing paste, applied on a felt wheel (TDV; USA) for 60 seconds [33].

\section{Surface roughness}

The surface roughness of the specimens was measured with a profilometer (TR200, Qualitest; Germany). Five different points (in the center and sides) of each specimen was measured and the mean value of surface roughness was recorded by $\mu \mathrm{m}$ [33].

The specimens were sterilized in an autoclave at $121^{\circ} \mathrm{C}$ and $15 \mathrm{psi}$ for 15 minutes [33].

\section{Bacterial biofilm adhesion}

The bacteria used in this study was Streptococcus Mutans (PTCC1683: Iran) to obtain a fresh bacterial culture. S. mutans was plated onto a brain heart infusion (BHI) agar (Darvash: Iran) and incubated in a $\mathrm{CO}_{2}$ atmosphere at $37{ }^{\circ} \mathrm{C}$ for 24 hours. After incubation, two colonies from fresh cultures were transferred into a tube containing $5 \mathrm{ml}$ sterile physiological solution $(0.9 \%$ sodium chloride) to obtain a bacterial suspension with turbidity equivalent to standard concentration of $0.5 \mathrm{Mc}$.Farland of barium sulfate in a 
Table 1: Composition, type and filler loading of the composite resins tested.

\begin{tabular}{|c|c|c|c|c|c|c|}
\hline Composite type & Color & Fillers & $\begin{array}{l}\text { Mean size of fillers } \\
(\mu \mathrm{m})\end{array}$ & $\begin{array}{l}\text { Filler loading } \% \\
\text { weight }\end{array}$ & $\begin{array}{l}\text { Filler loading } \% \\
\text { volume }\end{array}$ & Resin matrix \\
\hline \multirow{2}{*}{ Filtek P90 } & \multirow{2}{*}{ A2 } & quartz and & $0.47 \mu \mathrm{m}$ & 76 & 55 & Silorane (oxirane and siloxane) \\
\hline & & ytterbium fluoride & $0.1-2 \mu \mathrm{m}$ & & & \\
\hline \multirow{2}{*}{ Filtek Z250xt } & \multirow{2}{*}{ A2 } & $\begin{array}{l}\text { Surface-modified } \\
\text { zirconia/silica }\end{array}$ & $0.1-10 \mu \mathrm{m}$ & 82 & 68 & $\begin{array}{c}\text { BIS-GMA, UDMA,BIS-EMA, PEGDMA, } \\
\text { TEGDMA }\end{array}$ \\
\hline & & $\begin{array}{c}\text { Nanosilica particles and } \\
\text { nanoclusters }\end{array}$ & $20 \mathrm{~nm}$ & & & \\
\hline
\end{tabular}

Table 2: Mean and standard deviation of the surface roughness (Ro).

\begin{tabular}{|c|c|c|c|c|}
\hline Composite type & Surface treatment techniques & Specimens & Mean value of Ro. $m \mu$ & Standard deviation \\
\hline \multirow{5}{*}{ P90 } & Mylar & 30 & 0.046 & 0.017 \\
\hline & Disc & 30 & 0.105 & 0.035 \\
\hline & Rubber point & 30 & 0.117 & 0.024 \\
\hline & p.paste & 30 & 0.108 & 0.029 \\
\hline & Sum & 120 & 0.094 & 0.039 \\
\hline \multirow{5}{*}{ Z250xt } & Mylar & 30 & 0.045 & 0.03 \\
\hline & Disc & 30 & 0.113 & 0.036 \\
\hline & Rubber point & 30 & 0.133 & 0.028 \\
\hline & p.paste & 30 & 0.12 & 0.036 \\
\hline & Sum & 120 & 0.103 & 0.047 \\
\hline
\end{tabular}

tube $[32,33]$. The suspension was concentrated as $10^{8}$ bacteria $\mathrm{ml}^{-1}$ by counting the bacterial cells in a spectrophotometer.

To measure the bacterial adherence, sterile TSB (Tripticase Soy Broth) (and 24-well polystyrene tissue culture plates were used (Figure 1). In each well of these plates; one specimen, $1.5 \mathrm{ml}$ of sterile culture medium (TSB) (Darvash: Iran) and $0.1 \mathrm{ml}$ of standardized S.Mutans suspension were placed. The plates were incubated in a $\mathrm{CO}_{2}$ atmosphere at $37^{\circ} \mathrm{C}$ for 24 hours. The specimens were removed from the well and irrigated twice with sterile PSB $(\mathrm{PH}=7.2)$ to remove the loosely attached materials. Each specimen was placed in a tube of $3 \mathrm{ml}$ sterile physiological solution and the tubes were placed in an ultrasonic bath with the frequency of 25 Hertz for 10 minutes to separate the biofilms from specimens (Figure 2).

Serial dilutions $10^{-1}-10^{-3}$ were prepared from the each suspension containing separated biofilms. For calculating the amount of bacteria in these diluted suspensions, $0.1 \mathrm{ml}$ of the suspension was inoculated onto the plate of $\mathrm{BHI}$ agar and was incubated in $\mathrm{CO}_{2}$ atmosphere at $37^{\circ} \mathrm{C}$ for 24 hours. After the incubation, the S.Mutans colonies on the agar were counted by the colony counter (trade mark) and the mean values were recorded by $\mathrm{CFU} / \mathrm{ml}$ and converted into logarithmic $\left(\log _{10}\right)$ values [32]. Finally, the obtained data were analyzed using the Two-way ANOVA and Bonferroni tests. All analyses were processed using SPSS11 (SPSS Inc., Chicago, Illinois). The level of significant difference was set at $\mathrm{P}<0.05$.

\section{Results}

The mean and standard deviation values of the surface roughness $(\mathrm{Ro}=\mu \mathrm{m})$ of two groups of composites with different surface treatments are stated in Table 2.

Two way ANOVA indicated that the surface roughness values had significant differences depending on the composite resin type (P90,
Table 3: Differences between surface roughness values ( $P$-value $<0.001)$.

\begin{tabular}{|c|c|c|c|c|}
\hline \multirow{2}{*}{ Composite type } & \multicolumn{4}{|c|}{ Surface treatment techniques Mean value \pm standard } \\
deviation of Ro.
\end{tabular}

Uppercase letters indicate significant differences between columns. Lowercase letters indicate significant differences between rows.

Z250XT) and the surface treatment techniques (Mylar strips, Discs, Rubber points, Polishing pastes) table(3). The surface roughness value was significantly higher in Z250XT than P90. The One-way ANOVA and Bonferroni analysis revealed that the surface roughness value by only using the mylar strip in each composite types (P90, Z250XT) was significantly lower than the three surface treatment types (Discs, Rubber points, Polishing pastes). ( $P$ value $<0.001$ ) While the surface roughness values among three surface treatment types had no significant differences. The analysis between the two types of composite in each group of surface treatment revealed that the surface roughness value in the rubber point group was significantly $(P$ value $=0.025)$ higher than P90.

\section{Bacterial adhesion}

The mean and standard deviation of the bacterial adhesion amount on P90 and Z250XT with different surface treatments are stated in Table 4. The Two-way ANOVA analysis revealed that each of the composite type and surface treatments had significant effect on bacterial accumulation, while P90 had a higher value of bacterial adhesion in contrast with Z250XT.(0.0353 CFU/ml) Table 5.

As stated in Table 4, the amount of bacterial accumulation on the surface of $\mathrm{P} 90$ group, using the mylar strip without any surface treatment had a significant higher value than three other polishing techniques. While the significant lower value was shown in using 
Table 4: Mean and standard deviation of bacterial adhesion.

\begin{tabular}{|c|c|c|c|c|}
\hline Composite type & Surface treatment techniques & Specimens & Mean bacterial plaque adhesionlog (CFU/ml) & Standard Deviation \\
\hline \multirow{5}{*}{ P90 } & Mylar & 30 & 6.65 & 0.304 \\
\hline & Disc & 30 & 4.95 & 0.093 \\
\hline & Rubber point & 30 & 4.79 & 0.143 \\
\hline & p.paste & 30 & 5.05 & 0.24 \\
\hline & Sum & 120 & 5.36 & 0.781 \\
\hline \multirow{5}{*}{ Z250xt } & Mylar & 30 & 4.92 & 0.089 \\
\hline & Disc & 30 & 5.03 & 0.47 \\
\hline & Rubber point & 30 & 5.07 & 0.417 \\
\hline & p.paste & 30 & 5.01 & 0.37 \\
\hline & Sum & 120 & 5 & 0.367 \\
\hline
\end{tabular}

Table 5: Differences between bacterial plaque adhesion $(P$ value $<0.001)$

\begin{tabular}{|c|c|c|c|c|}
\hline Composite type & Surface treatment techniques & Specimens & Mean bacterial plaque adhesionlog(CFU/ml) & Standard Deviation \\
\hline \multirow{5}{*}{ P90 } & Mylar & 30 & 6.65 & 0.304 \\
\hline & Disc & 30 & 4.95 & 0.093 \\
\hline & Rubber point & 30 & 4.79 & 0.143 \\
\hline & p.paste & 30 & 5.05 & 0.24 \\
\hline & Sum & 120 & 5.36 & 0.781 \\
\hline \multirow{5}{*}{ Z250xt } & Mylar & 30 & 4.92 & 0.089 \\
\hline & Disc & 30 & 5.03 & 0.47 \\
\hline & Rubber point & 30 & 5.07 & 0.417 \\
\hline & p.paste & 30 & 5.01 & 0.37 \\
\hline & Sum & 120 & 5 & 0.367 \\
\hline
\end{tabular}

Uppercase letters indicate significant differences between columns.

Lowercase letters indicate significant differences between rows.

the rubber point. While in Z250XT group, no significant differences were seen between the surface treatment types Table 4 . The analysis of bacterial accumulation between the two composites in each surface treatment group revealed that the mean value on P90 was significantly higher than Z250xt in mylar group. While, in the rubberpoint group there was a higher mean value on Z250xt than P90.

\section{Discussion}

Clinical surface treatment techniques such as finishing and polishing have a major role in enhancement of esthetics, longevity and performance of the composite resins. Polishing procedures are performed to decrease the surface roughness and cracks produced by the finishing devices on the composite surface. While increases the clinical longevity of the restorations and decreases the biofilm accumulation [4-6]. Therefore, polishing techniques on composite surfaces decreases the periodontal diseases, marginal discoloration and secondary caries $[8,11]$. Silorane-based composites are known as low polymerization shrinkage $(<1 \%)$ composites versus methacrylate based composites. The polymerization process is a cationic ring opening reaction and resemble higher hydrophobicity and lower water sorption characteristics [17,34-37]. In addition to improved mechanical properties of these materials, biologic characteristics such as their effect on bacterial plaque accumulation should be evaluated. In general, the tendency of the biofilm adhesion to the restorations is as important as the restorations life time in the oral cavity. The adherence of the bacteria on the composite resin surfaces has an important role in secondary caries promotion [38]. This study evaluated the effect of different polishing techniques on surface roughness and bacterial adhesion of two composite types. (Z250xt and P90) As result, composite resin types and different surface treatments had a significant effect on surface roughness and bacterial plaque accumulation. The higher surface roughness value in each composite group was produced by the rubberpoint.

The significant lower surface roughness value was observed in group of composites with the mylar strips, compared to the three polishing techniques. The surface roughness values in Z250xt group finished with rubberpoint was significantly higher than P90 group with same treatment. Infact, the smoothest surface in the tooth colored materials was in the mylar strip groups. These differences between the surface roughness values on composite surfaces can be related to the size and amount of the particles in each composite type. As shown in Table 1, the Z250xt; is a hybrid composite which has filler particles greater than silica and zirconia with the size of $0.1-10 \mu \mathrm{m}$ and nanofill and nanocluster particles with the size of $20 \mathrm{~nm}$ which occupy $82 \%$ by weight of the composite. While the P90 has quartz and yetribium floride particles with the size of $0.1-2 \mu \mathrm{m}$ and $76 \%$ by weight of filler content. As Sakaguchi and Powers stated, nanohybrid composites consist of large particles ( 0.4 to 5 microns) with added nanocluster sized particles. Thus, abrasion causes the larger filler particles to pluck out and leads to higher surface roughness [39]. Z250xt has 
higher amount of inorganic fillers (silica and zirconia) Compared to P90. Hahnel, et al. stated that polishing of filled resins cause a higher fracture of inorganic components in the surface layer [40]. Although this finding confirms the significant level of surface roughness, in Z250xt compared to P90; but in Jones findings, the minimal clinical level of significant surface roughness is $0.5 \mu \mathrm{m}$. While the mean differences in surface roughness of the two composites is $0.009 \mu \mathrm{m}$ which can be disregarded. As stated in Table 3, the bacterial plaque accumulation in Z250xt is significantly less than P90. The bacterial accumulation on the composite resin surfaces are related to the increase of surface roughness, degradation of the restorative material due to producing acids by the cariogenic microorganisms, hydrolysis of the resin matrix and decrease in surface micro hardness [39]. Little amounts of unpolymerized products of the resin monomers and biodegradation products of the resins affect the bacterial growth in conjunction with resin restorative materials [39]. Many studies reported that $25 \%$ of the carbon double bonds in methacrylate based composites remain unreacted in the bulk of the material [39]. Also, the degree of conversion amount in silorane-based composites is significantly less than methacrylate based composites. Porto, et al. stated that the reason is slower polymerization interaction [41]. Therefore the higher amount of bacterial accumulation in P90 compared to Z250xt can be related to higher amount of resin matrix in this type of composite. In the P90 group, as shown in table 4, although there was less surface roughness in the subgroup with mylar strip only compared to other three polishing techniques, but the bacterial plaque accumulation was higher than the three subgroups. It is obvious that the smoothest surface of the composite resin materials is achieved with mylar strips without any finishing and polishing techniques. But it should be noticed that this surface has higher level of resin amount and therefore has resistance to abrasion [42]. In the fact, applying finishing and polishing techniques to remove the rich monomer layer on composite surface is necessary [43].

Therefore, because of higher level of resin in matrix and less degree of conversion in the P90, the bacterial plaque accumulation in the subgroup with mylar strips which has unpolymerized resin on the surface is higher. According to Table 5, bacterial adhesion on Z250xt, was the same between different surface treatments. Although it is known that smooth surfaces have less ability than rough surfaces to absorb bacterial adhesion. Bollen, et al. stated that, increase in surface roughness value from $0.2 \mu \mathrm{m}$ threshold which increases the amount of surface energy, have significant effect on bacterial plaque accumulation on dental material surfaces [44]. Therefore, as the mean differences of surface roughness among the surface treatments are less than $0.2 \mu \mathrm{m}$, then it can be suggested that there is no significant differences in bacterial plaque accumulation between the sub groups. In the fact, the amounts of differences in surface roughness values in this study are negligible for clinical situations that can be concluded that, the most important reason for bacterial plaque accumulation is the type and composition of the composites which is the same as Ono, Ikeda and Gharachahi conclusions [1,10]. Ionescu's studies revealed that there is significant relation between composite resin composition and bacterial plaque accumulation [45]. Priera concluded that the least amount of bacterial plaque accumulation is in subgroups of composites with mylar strips while in this study the bacterial amount was higher in P90with mylar strips whereas there was no significant differences between subgroups in Z250xt and this was explained by different composition in groups of composites [32]. Kontorski, et al. also stated that composites with higher surface roughness have higher bacterial plaque accumulation, while in this study, the composition of the composite and the surface roughness value together have significant effects on the plaque accumulation.

\section{References}

1. Ono M , Nikaido T, Ikeda M, Imat S, Hanada N, Tagami J, et al. Surface properties of resin composite materials relative to biofilm formation. Dent Mater J. 2007; 26: 613-622.

2. Manhart J. Direct composite restorations in posterior region: a case history using a nanohybrid composite. Dent Today.2004; 23: 66-70.

3. Turssi CP, Faraoni- Romano JJ, Serra MC. Comparative study of wear behavior of composites for posterior restorations. J Mater Sci Mater Med. 2007; 18: 143-147

4. Neme AL, Frazier KB, Roeder LB, Debner TL. Effect of prophylactic polishing protocols on the surface roughness of esthetic restorative materials. Oper Dent. 2002; 27: 50-58.

5. Baseren M. Surface roughness of nanofill and nanohybrid composite resin and ormocer-based tooth colored restorative materials after several finishing and polishing procedure. J Biomater Appl. 2004; 19: 121-134.

6. Sarac D, Sarac YS, Kulunk S, Ural C, Kulunk T. The effect of polishing techniques on the surface roughness and color change of composite resins. J Prosthet Dent. 2006; 96: 33-40.

7. Uctasli MB, Arisu HD, Omurlu H, Eliguzeloglu E, Ozcan S, Ergun G. The effect of different finishing and polishing systems on the surface roughness of different composite restorative materials. J Contemp Dent Pract. 2007; 8: 89-96.

8. Barbosa SH, Zanata RL, Navarro MF, Nunes OB. Effect of different finishing and polishing techniques on the surface roughness of microfilled, hybrid and packable composite resins. Braz Dent J. 2005; 16: 39-44.

9. Jung M, Eichelberger K, Klimek J. Surface geometry of four nanofiller and one hybrid composite after one-step and multiple-step polishing. Oper Dent. 2007; 32: 347-55.

10. Ikeda M, Matin K, Nikaido T, Foxton RM, Tagami J. Effect of surface characteristics on adherence of $\mathrm{S}$. mutans biofilms to indirect resin composites. Dent Mater J. 2007; 26: 915-23.

11. Attar N. The effect of finishing and polishing procedures on the surface roughness of composite resin materials. J Contemp Dent Pract. 2007; 8: 27 35.

12. Koh R, Neiva G, Dennison J, Yaman P. Finishing systems on the final surface roughness of composites. J Contemp Dent Pract. 2008; 9: 138-145.

13. Quirynen M. The clinical meaning of the surface roughness and the surface free energy of intra-oral hard substrata on the microbiology of the supra- and subgingival plaque: results of in vitro and in vivo experiments. J Dent. 1994; 1: S13-6.

14. Kawai K, Urano M, Ebisu S. Effect of surface roughness of porcelain on adhesion of bacteria and their synthesizing glucans. J Prosthet Dent. 2000; 83: 664-667

15. Carlen A, Nikdel K, Wennerberg A, Holmberg K, Olsson J. Surface characteristics and in vitro biofilm formation on glass ionomer and composite resin. Biomaterials. 2001; 22: 481-487

16. Yap AU, Yap SH, Teo CK, Ng JJ. Finishing/polishing of composite and compomer restoratives: effectiveness of one-step systems. Oper Dent. 2004; 29: $275-279$

17. Weinmann W, Thalacker C, Guggenberger R. Siloranes in dental composites Dent Mater. 2005; 21: 68-74.

18. Liporoni P, Paulillo LA, Cury JA, Dos Santos Dias CT, Paradella TC. Surface finishing of resin-modified glass ionomer. Gen Dent. 2003; 51: 541-543. 
19. Turkun LS, Turkun M. The effect of one-step polishing system on the surface roughness of three esthetic resin composite materials. Oper Dent. 2004; 29 203-211.

20. Uctasli MB, Bala O, Gullu A. Surface roughness of flowable and packable composite resin materials after finishing with abrasive discs. J Oral Rehabil. 2004; 31: 1197-202.

21. Venturini D, Cenci MS, Demarco FF, Camacho GB, Powers JM. Effect of polishing techniques and time on surface roughness, hardness and microleakage of resin composite restorations. Oper Dent. 2006; 31: 11-7.

22. Reis AF, Giannini M, Lovadino JR, dos Santos Dias CT. The effect of six polishing systems on the surface roughness of two packable resin-based composites. Am J Dent. 2002; 15: 193-197.

23. Celik C, Ozgunaltay G. Effect of finishing and polishing procedures on surface roughness of tooth-colored materials. Quintessence Int. 2009; 40: 783-789.

24. Montanaro L, Campoccia D, Rizzi S, Donati ME, Breschi L, Prati C, et al. Evaluation of bacterial adhesion of Streptococcus mutans on dental restorative materials. Biomaterials. 2004; 25: 4457-4463.

25. Eick S, Glockmann E, Brandl B, Pfister W. Adherence of Streptococcus mutans to various restorative materials in a continuous flow system. J Oral Rehabil. 2004; 31: 278-285.

26. De Munck J, Van Landuyt K, Peumans M, Poitevin A, Lambrechts P, Braem $M$, et al. A critical review of the durability of adhesion to tooth tissue: methods and results. J Dent Res. 2005; 84: 118-132.

27. Lobo MM, Gonçalves RB, Ambrosano GM, Pimenta LA. Chemical or microbiological models of secondary caries development around different dental restorative materials. J Biomed Mater Res B Appl Biomater. 2005; 74: 725-731.

28. Konishi N, Torii Y, Kurosaki A, Takatsuka T, Itota T, Yoshiyama M. Confocal laser scanning microscopic analysis of early plaque formed on resin composite and human enamel. J Oral Rehabil. 2003; 30: 790-795.

29. Buergers R, Rosentritt M, Handel G. Bacterial adhesion of Streptococcus mutans to provisional fixed prosthodontic material. J Prosthet Dent. 2007, 98: 461-469.

30. Steinberg D, Eyal S. Early formation of Streptococcus sobrinus biofilm on various dental restorative materials. J Dent. 2002; 30: 47-51.

31. Auschill TM, Arweiler NB, Brecx M, Reich E, Sculean A, Netuschil L. The effect of dental restorative materials on dental biofilm. Eur J Oral Sci. 2002; 110: $48-53$

32. Pereira CA, Eskelson E, Cavalli V, Liporoni PC, Jorge AO, do Rego MA Streptococcus mutans biofilm adhesion on composite resin surfaces afte different finishing and polishing techniques. Oper Dent. 2011; 36: 311-317.

33. Aykent F, Yondem I, Ozyesil AG, Gunal SK, Avunduk MC, Ozkan S. Effect of different finishing techniques for restorative materials on surface roughness and bacterial adhesion. J Prosthet Dent. 2010; 103: 221-227.

34. Guggenberger R, Weinmann W. Exploring beyond methacrylates. Am J Dent 2000; 13: 82D-84D

35. Palin WM, Fleming GJ, Burke FJ, Marquis PM, Randall RC. The influence of short and medium-term water immersion on the hydrolytic stability of novel low-shrink dental composites. Dent Mater. 2005; 21: 852-863.

36. Palin WM, Fleming GJ, Nathwani H, Burke FJ, Randall RC. In vitro cuspal deflection and microleakage of maxillary premolars restored with novel lowshrink dental composites. Dent Mater. 2005; 21: 324-335.

37. Eick JD, Kotha SP, Chappelow CC, Kilway KV, Giese GJ, Glaros AG, et al. Properties of silorane-based dental resins and composites containing a stress-reducing monomer. Dent Mater. 2007; 23: 1011-1017.

38. Yamamoto K, Ohashi S, Taki E, Hirata K. Adherence of oral streptococci to composite resin of varying surface roughness. Dent Mater J. 1996; 15: 201-204

39. Powers JM, Sakaguchi RL. Craig's restorative dental materials. 13th ed. St. Louis, MO: Mosby Inc.; 2012: 19, 20, 162-192.

40. Hahnel S, Rosentritt M, Bürgers R, Handel G. Adhesion of Streptococcus mutans NCTC 10449 to artificial teeth: an in vitro study. J Prosthet Dent. 2008; 100: 309-315.

41. Porto IC, de Aguiar FH, Brandt WC, Liporoni PC. Mechanical and physical properties of silorane and methacrylate-based composites. J Dent. 2013; 41: 732-739.

42. Roberson TM, Heyman HO, Swift EJ. Sturdevant's Art and Science of Operative Dentistry.6th ed. Mosby; 2013: 216-223.

43. Wassell RW, McCabe JF, Walls AW. Wear characteristics in a two-body wear test. Dent Mater. 1994; 10: 269-274
Austin J Dent - Volume 5 Issue 4 - 2018

ISSN : 2381-9189| www.austinpublishinggroup.com

Behniafar et al. (C) All rights are reserved
Citation: Daneshkazemi AR, Davari AR, Shirkhoda M, Zandi H and Behniafar B. Effect of Three Different Polishing Techniques on Surface Roughness and Bacterial Adhesion of Two Composite Resin. Austin J Dent. 2018; 5(4): 1110 